\title{
Relationship Between Political Apointee and Bureaucracy in Civil Service System
}

\author{
Martinus Sardi ${ }^{1, *}$ Bagus Sarnawa ${ }^{1}$ \\ ${ }^{\text {I}}$ Faculty of Law, Universitas Muhammadiyah Yogyakarta, Indonesia \\ *Corresponding author. Email: msardi@law.umy.ac.id
}

\begin{abstract}
In Indonesia, governmental bureaucracy is commonly occupied by the political apointee and bureaucratic careers. The existence of the political apointee in the bureaucracy is one of the consequences of the democratic system in Indonesia. This research aims to analyze the relationship between political apointee and bureaucratic careers in the civil service system in Indonesia. The political apointee generally tends to support the political party to which he associates with. While of that, bureaucratic careers should work for the government goals and the developments. The relationship between political apointee and bureaucracy careers are about "who dominates whom" and "who controlls whom". Political apointee strictly influenced the bureaucracy in most cases the bureaucracy is merely subordinates of the political apointee such phenomenon is found. During the Old Order, the New Order, and the Reformation Era. in the Old Order. The political apointee in bureaucracy commonly will ask all new comers to join the political orientation of them. Similarly, governmental bureaucracy in the New Order period, was controlled and became subordinate of Golongan Karya (Golkar). At the time, Golkar was not a political party but it has a role as one of a political party to join the general election. As a ruling party, Golkar ask all the civil service to be a member of them. In the Reformation Era, the bureaucracy still becoming subordinates of political apointee. Since the authority to promote, redeployment, and discharge the staffs or the civil service are the right of political officers, hence the officers will be easily to influence the staffs for joining their political orientations.
\end{abstract}

Keywords: The Political Apointee, Bureaucracy, Civil Service System

\section{INTRODUCTION}

Since Indonesia's independence, starting from the old order, the new order and the reform order, there has been a dynamic relationship between political officials and the bureaucracy. During the old and new order periods, the bureaucracy became a sub-ordination of political officials, while during the reform era, there was an attempt to align the bureaucratic position with political officials. During the old order, bureaucracy became a sub-ordinate of political officials, this happened because the governing body was led by political officials from political parties, political officials then intervened in the political order in order to gain political support from the bureaucracy, as well as in the new order. Whereas during the reform period, based on research by the Indonesian Institute of Sciences (2006), there were a number of factors that caused the bureaucracy to become a sub-ordinate of political officials, namely the strength of personality that instilled influence on the bureaucracy, the desire of the bureaucrats themselves to immediately get a career path faster, weak institution socialization, as well as multiple interpretations or monopolistic interpretations of existing rules, patron-client relations, and the role of shadow bureaucracy

So far the study of the relationship between political officials and bureaucracy looks at the relationship between patron and client, where bureaucracy and political officials are seen as the relationship of who controls who (Scott, 1972; Lande, 1977; Carino, 1994; Sukritamma, 2010; Azhari, 2011). Whereas the problem of bureaucracy which is equal to political officials so that it does not become a sub-ordination of political officials is very important.

The purpose of this research is to complement the existing study deficiencies by mapping the pattern of relations between political officials and bureaucracy so that they can build a model of bureaucratic independence that is not intervened by political officials.

This paper is based on the argument that the bureaucracy in Indonesia from the old order to the present time has experienced subordination of political officials, resulting in the emergence of bureaucratic politicization. As a result, the practice of democracy is disrupted, for example in the holding of general elections both for presidential elections, legislative 
members and regional heads, bureaucracy is not neutral

\section{MATERIAL AND METOD}

This research was conducted in Indonesia with the theme of bureaucratic relations and political officials. This type of research is qualitative research. The data needed in this qualitative research are primary data and secondary data.

Primary data were obtained through field research by conducting free interviews with informants. Interviews were conducted with experts and practitioners including, among others, the Deputy for Development of the Republic of Indonesia Civil Service Agency, Members of Commission II of the Indonesian House of Representatives, the Indonesian Civil Apparatus Commission and the political officials of the Governor of Central Java. Whereas secondary data or library materials are obtained through literature study consisting of primary legal materials, secondary legal materials and tertiary legal materials which will then be reviewed to formulate the results of research and draw conclusions of research in relation to the problem under study. This secondary data includes legal material in the form of laws and regulations, including: the 1945 Constitution of the Republic of Indonesia; Law Number 18 of 1961 concerning Basic Personnel Provisions; Law Number 8 of 1974 concerning Personnel Principles; Law Number 43 of 1999 concerning Amendment to Law Number 8 of 1974 concerning Basic Personnel; Law number 5 of 2014 concerning State Civil Apparatus; other laws and regulations both Government Regulations, Presidential Decrees, Ministerial Regulations and others. Also used are minutes of proceedings for the drafting of Law Number 8 of 1974, Law number 43 of 1999 and Law number 5 of 2014. In addition, it also uses various books, news, articles and other materials specifically related to the relations between political officials and bureaucracy

The analysis used is content analysis by categorizing and discovering the concept of neutrality in the State Civil Apparatus. The collected data will then be sorted in qualitative data. Qualitative data will be analyzed by content analysis. Interpretation of data using theoretical interpretation techniques means that researchers do not use just one theory to understand data but use several theories as a comparison and this theory functions as a directing analysis

\section{RESULT}

The relationship between political officials and the bureaucracy from the old order to the present period. During the New Order until the Reform Order today, it shows that the orientation of the authorities is still very strong. Values and symbols show how political officials perceive themselves more as rulers than as servants or servants of society. This can be seen in each of these periods, in the old order, bureaucracy was contaminated with ideology brought by political parties, many cases occurred where political parties that lead a ministry will be embedded party influence in the ministry, as a result all bureaucracies in the ministry certainly is a supporter of the political party, as a result Civil Servants are compartmentalized

During the New Order era, the bureaucracy had a single loyalty, monoloyalty) to the political power that won a single majority in the general election, the Work Group. This monoloyalty policy has become the government's political strategy to dominate the bureaucracy

During the reform era, there was bureaucracy politicization in the form of mobilization. This mode is most often found before the implementation of regional head elections in each region. Other modes include the use of official vehicles, involvement of regional officials, use of houses of worship, use of official houses, and use of popular government programs (poor rice). Based on data from the Election Oversight Body until early May 2010, 1,599 violations have been found in the regional head election in 2010.

According to Thoha (2010) the relationship between bureaucracy and political officials (political leadership) is something that is a constant relationship between the function of control and domination and there are two main forms of alternative solutions, namely whether bureaucracy as a subordination of politics (executive ascendary) or bureaucracy is aligned with politics (bureaucracy) sublation). While Carino (1994) states that relating to the relationship between the regional head as a political official and the bureaucracy, it is said by Ledivina Carino that the relationship is a steady or constant relationship. This relationship will raise the issue of who controls who, who controls who and who also controls who.

Mengistu and Vogel (2006) found that related to the relationship between political officials and bureaucracy, in the leadership of Ethiopian executive bureaucracy (which is not neutral) strongly encouraged the occurrence of partisan bureaucracy and spoils system which eventually became a characteristic of bureaucracies who always only focused on personal gain. A similar finding was made by Meier and O'Toole (2006) who stated that political officials always controlled the bureaucracy. Relations as above occur due to the pattern of client patrons, as mentioned by Scott (1972), namely:

The patron-client relationship-an exchange relationship between roles-may be defined as a special case of dyadic (two person) ties involving a large instumental friendship in which an individual of higher socioeconomic status (patron) uses his own influence and resources to provide protection or benefits, or both, for a person of lower status (client) who, for his part, reciprocates by offering general 
support and assistance, including personal services, to the patron

Also as Lande (1977) mentioned:

A patron client relationship is a vertical dyadic, i.e, an alliance between two person of unequal status, power or resources each of whom finds it useful to have as anally someone superior member of such an alliance is called a patron. The inferior member is called his client.

Patronage comes into being because of an unequal relationship but mutual needs. On the one hand, patrons emerge as individuals who have advantages both in terms of wealth, status and influence. On the other hand, the client is present as a member of the community who does not have the resources of a patron. Therefore, the relationship in this context can be interpreted as a relationship based on the "exchange of interests." The basic assumption of this conceptual framework lays a way of thinking that stresses that the relationship will occur if both parties can benefit from the relationship they have. At least the mechanism is like this: the patron group provides economic assistance and protection to the client group or subordinates; and in return for the gift, then the client group provides devotion and loyalty to the patron (Agustino, 2014)

Empirically, in the practice of relations between political officials and bureaucracy in Indonesia is executive acendency. As mentioned Untung Muhdiarta (2016)

the number of regional heads of promoting employees in positions with more use of political considerations rather than competence, yet staffing rules do not allow it. While research LIPI in Agustino (2009) on The local elections in three areas, Kutai, reeds and Gowa, shows that the involvement or the use of civil servants (the bureaucracy) in the elections can not be avoided, as most civil servants are still siding with the heads of certain regions, PNS wedged in the position of being "power tool" local political elites in exchange position and its own profit and loss calculations. This threatens the promotion of career civil servants who try to work professionally (neutral) with the uncertainty of their promotion of employee career for himself. Employees who are not supporters of candidates winners, moved into did not have a position or move the path of duty
In the old order, bureaucracy was contaminated by various ideological differences brought by political parties, many cases occurred where political parties that lead a ministry would be embedded party influence in the ministry, the bureaucrats in the ministry were certainly supporters of the political parties, as a result the bureaucracy becomes fragmented as a result of the political and government situation. On the other hand, political parties through political officials who represent the party instill their influence on the bureaucracy and use the bureaucracy as the building block of their organization. Political parties have a period of influence and support period in each department, or even dominate the department. Thus political intervention in bureaucratic life is enormous

During the new order, efforts to realize to eliminate political party intervention to the bureaucracy as happened in the old order then bureaucracy was cleansed from party political influences through the issuance of the Minister of Domestic Affairs Regulation No. 12 of 1968 which placed the civil bureaucracy under the control of the central government. Under this regulation, every bureaucrat in the department is ordered to be loyal only to the state and nation, and is prohibited from becoming a member of a political party. This step is intended to consolidate the government bureaucracy and reform the position of the bureaucracy in political life. The unification of the government bureaucracy corps began in 1966 through the establishment of the Ministry of Home Affairs (Kokar Mendagri) Employee Corps as the forerunner to the Indonesian Employee Corps (KORPRI). The institution was actually designed for the political interests of winning the Group of Work (Golkar) in the 1971 election. The success of the Minister of Home Affairs in winning the Golkar absolutely in the 1971 election, then encouraged the government to expand its membership to all government bureaucratic apparatus from various departments or agencies, both at the level central and regional. The integration of the civil bureaucracy into one forum was truly carried out through the establishment of KORPRI so that the Korpri became the only forum that accommodated the aspirations of government bureaucratic employees. The politics of uniformity is enforced within the government bureaucracy. The aspect of bureaucratic organization life which was first targeted by political policy was the development of the spirit of the korsa of the government bureaucratic apparatus. The loyalty of the government bureaucracy is aimed at the state and the government, not to political parties. This rule is still the same substance as the rule during the Old Order administration

During the Reform Order, the situation as in the old order reoccurred. Political parties appeared. Political parties that form a coalition and win the General Elections of the President and Vice President, get prizes for controlling the Departments, as a result the bureaucracy has become a sub-ordinate of political officials who represent political parties. As a result, 
there was a bureaucracy politicization in the holding of general elections both for the election of President / Vice President, legislative members and regional heads in modes such as: the use of development programs and government budgets as a means of election campaigns, distributing money and or material to voters, using office facilities used for party needs, using office facilities for political party campaigns, bureaucratic support to political parties either secretly or openly. This happens because political officials are officials of the custodians who have the authority to appoint, move and stop bureaucracy. This means that a bureaucratic career depends on political officials.

\section{CONCLUSION}

This research shows that since the independence of the Indonesian state, from the old order to the reform order, there was a bureaucratic sub-ordination by political officials. This happened as a result of the existing legal instruments placing the position of political officials in positions that were superior to the bureaucracy. So it is necessary to reform the political system in Indonesia, namely the regulation that political officials from political parties are obliged to resign from political party membership, so that when the political official occupies a political position, the official is no longer a representation of a political party so that he does not intervene in the political bureaucracy. On the other hand, a more rigid arrangement regarding bureaucracy is neutral and not intervened by political officials.

\section{REFERENCES}

Berhanu Mengistu and Elizabeth Vogel, 2006, "Bureaucratic Neutrality among Competing Bureaucratic Values in an Ethnic Federalism:
The Case of Ethiopia", Public Administration Review, March-April 2006

Kenneth J. Meier and Laurence J. O'Toole Jr, 2006, "Political Control versus Bureaucratic Values: Reframing the Debate"; Public Administration Review, Vol. 66, No. 2 (Mar.-Apr., 2006)

Lande, C.H. 1977. Introduction: The Dyadic Basic of Clientalism dalam Steffen W. Schmidt \&James C. Scott (eds.). Friends, followers and factions a reader in political clientalism, xiii - xxxvii. Berkeley: University of California Press

Ledivina Carino, 1994, Bureaucracy for Democracy: The Dynamics of Executive-Bureaucracy Interaction During Governmental Transitions, College of Public Administration, University of the Philippines

Leo Agustino, 2014, "Patronase Politik Era Reformasi : Analisis Pilkada di Kabupaten Talakar dan Propinsi Jambi”, Jurnal Administrasi Publik, Volume 11 Nomor 2, Oktober 2014

Miftah Thoha, 2010, Birokrasi dan Politik di Indonesia, Rajawali Press, Jakarta

Scott, J.C. 1972. "Patron-client politics and political change in Southeast Asia". American Political Science Review 66(1)

Untung Muhdiarta dkk, 2016, "Model Relationship Officers of Bureaucracy and PoliticalOfficials in the Government of Papua (A Study on the Placement of Officials Structurally Echelon II)", International Journal of Scientific and Research Publications, Volume 6, Issue 9, September 2016 